\title{
The influence of antecedents of supply chain integration on company performance
}

\author{
Rudyanto $^{a}$, Lyly Soemarni ${ }^{b}$, Rudy Pramono a and Agus Purwanto ${ }^{c^{*}}$
}

${ }^{a}$ Pelita Harapan University, Indonesia

${ }^{b}$ Pradita University, Indonesia

${ }^{c}$ Pelita Harapan University, Indonesia

\section{H R O N I C L E}

\begin{tabular}{l}
\hline Article history: \\
Received April 20,2020 \\
Received in revised format April \\
20,2020 \\
Accepted May 252020 \\
Available online \\
May 272020 \\
\hline Keywords: \\
Supply Chain Integration \\
Internal Integration \\
Customer Integration \\
Supplier Integration \\
Firm's Performance
\end{tabular}

\section{Introduction}

Increasing competition and a lack of ability to carry out internal integration of a company, causes companies to increasingly realize that company management needs to synchronize the overall strategy of internal operational activities with the company's supply chain partners. To realize this, the concept of supply chain integration (Supply Chain Integration) is of paramount importance (Palma-Mendoza, Neailey \& Roy, 2014). The tendency of previous supply chain studies (Jie, Parton \& Cox, 2013; Mackelprang, Robinson, Bernar, \& Webb, 2014; Xu, Huo \& Sun, 2014) is that there is a positive relationship between organizational levels with external and internal integration. Another study concluded that there was an improvement in company performance through improved customer service and cost reduction (Tseng \& Liao, 2015). In order for Supply Chain Integration to be effective, there needs to be supply chain management initiatives as follows: redesigning the business network, building stronger supplier network relationships and starting programs to reduce the time for ordering service products to deliver service products to consumers. The company is aware for the need of such initiatives, but there is still little evidence that these initiatives are implemented (Danese \& Romano, 2011).

\footnotetext{
* Corresponding author

E-mail address: agozpor@gmail.com (A. Purwanto)

(C) 2020 by the authors; licensee Growing Science. doi: $10.5267 /$ j.uscm.2020.5.006 
Supply Chain Integration has two benefits, namely: 1) companies can use supply chain partners to reduce the lack of internal resources, and enable companies to focus on core competencies and existing internal and external strengths to maximize productivity and profits; and 2) Supply Chain Integration enables companies to get tangible added value in all organizational, supplier and customer activities (Jin, Fawcett \& Fawcett, 2013; Klueber \& Okeefe, 2013; Papakiriakopoulos \& Pramatari, 2010). Several research findings on supply chain management prove the importance of tight supply chain integration relationships to improve company performance (Elmuti, Minnis \& Abebe, 2008; Gibson, Mentzer \& Cook, 2005), and some supply chain management research results also suggest the need for a chain integration approach supply systematically as one way - to deal with local and global competition; therefore, companies need supply chain partnership cooperation that is mutually beneficial (Lambert, Cooper \& Pagh, 2000; Wisner and Tan, 2000), and this would improve the intimacy between organizational functions which are the priorities to improve company performance (Zhao, Huo, Flynn \& Yeung, 2008). Global competitiveness is increasing, and product life cycles are diminishing. These are the two main factors that encourage organizations to change from a solitary framework - fighting in a competitive manner - to in turn work together with mutually beneficial supplier partners (Lambert \& Cooper, 2000; Wisner \& Tan, 2000). In this case, the company's supply chain must be able to align with the partner company's supply chain strategy in an effort to be more responsive to environmental changes and still maintain a competitive position (Richey, Chen, Upreti, Fawcett, \& Adams, 2009). This can be done by focusing and proactively establishing efficient supply chain partnership relationships, both between internal functions and external partners who are in the supply chain network (Qi, Zhao, \& Sheu, 2011; Narasimhan and Kim, 2002). Therefore, companies that are able to integrate processes with external suppliers and customers in one supply chain will be more successful in the long run (Frohlich \& Westbrook, 2001; Zailani \& Rajagopal, 2005). Several previous studies found that overall supply chain integration has a positive impact on improving company performance (Bagchi \& Chun Ha, 2005; Flynn, Huo \& Zhao, 2010; Kim, 2006; Zailani and Rajagopal, 2005), while the results of other studies prove integration has an positive impact on supply chain performance (Lee, Kwon \& Severance, 2007; Narasimhan and Kim, 2002) and company operational performance (Flynn, Huo \& Zhao, 2010; Frohlich and Westbrook, 2001). Lee, Kwon \& Severance (2007) see the main benefits of supply chain integration in terms of cost reduction, and focus on increasing company value, shareholder value and the value of all supply chain partners. Yeung, Selen, Zhang \& Huo (2009) stated that the main reason for supply chain integration is to combine all supplier partner resources with a propositional perspective on the company's value, thus enabling all supply chain partners of the company to have a performance advantage. Evans' (2015) research on the impact of supply chain integration strategy on processing industry performance shows that there is a positive relationship between internal factors, suppliers and customer integration and company performance.

From the description above, this study aims to examine the gaps in supply chain research, namely the influence of Supply Chain Integration on a company's Operational Performance, and analyze the development of the dimensions of supply chain characteristics (Vaart \& van Donk, 2008). Some previous supply chain studies only focus on the dimensions of Supply Chain Integration individually, specifically on customer and supplier integration (Cousins and Menguc, 2006; Homburg \& Stock, 2004; Koufteros, Cheng \& Lai, 2007); other supply chain studies only use various sets of definitions (Rosenzweig, Roth, \& Dean, 2003) to test Supply Chain Integration as a single construct. Thus, it is apparent that there are still incomplete supply chain concepts regarding Supply Chain Integration, namely from the external environment to the company's internal integration. The incomplete internal company integration and the development of the supply chain concept cause the findings of previous research results to be inconsistent because it forgets the important role of the company's internal integration in the implementation of supply chain integration and its effect on company performance (Das, Narasimhan \& Talluri., 2006; Devaraj, Krajewski \& Wei, 2007; Germain \& Iyer, 2006; Stank, Keller \& Closs, 2001).

\section{Theoretical Review}

\subsection{Antecedents of Supply Chain Integration}

Antecedents of Supply Chain Integration is the extent to which all organizational activities, activities of suppliers, customers and other supply chain partner members are integrated together in achieving the objectives of each company. Customer and supplier integration is often referred to as external integration, which is the level at which companies work together with external partners to develop strategies between organizations, practices, and collaborative processes achieving synchronization (Belvedere \& Grando, 2017; Stank, Keller \& Closs, 2001). Customer integration involves core competencies derived from the results of coordination with customers, while supplier integration involves core competencies related to coordination with major suppliers (Kim, 2006).

The focus of internal integration on activities within the company organization, extends to which the company arranges the strategies, practices, and processes of organizational activities into collaborative and synchronized processes to meet customer needs and desires (Cespedes, 1996; Kahn \& Mentzer, 1996; Kingman-Brundage, George \& Bowen, 1995); and interact efficiently with suppliers. Internal integration activities between company departments must function as part of the integration process with external parties and establish close and interactive cooperative relationships with customers and suppliers. These two perspectives are important, because they enable all members of the supply chain to move in an 

Grando, 2017).

The close relationship between the customer and company provides an opportunity to improve the accuracy of information on the demand for service products, which is able to reduce service product design costs, service product planning time and service product management costs, allowing more responsiveness to customer needs and desires. Moreover, customer integration creates opportunities to improve collaborative processes, and enables companies to reduce operating costs, create more value and be more responsive in detecting changes in market demand. Customer integration is related to customer satisfaction directly (Homburg \& Stock, 2004) and has an indirect relationship with the development and innovation of service products (Koufteros, Cheng \& Lai, 2007; Song \& Di Benedetto, 2008).

Several previous studies have shown the importance of supply chain integration on company performance (Droge, Jayaram \& Vickery, 2004; Frohlich and Westbrook 2001; Zailani and Rajagopal 2005). Several studies have also tested the validity of integration (Cousins and Menguc, 2006; Danese and Romano, 2011; Giminez, der Vaart \& van Don, 2012) and concluded that external supply chain integration cannot improve a company's operational performance since supply chain integration only increases performance when a highly intimate relationship with the supplier exists.

Bask \& Juga (2001) argue that intensive integration is not necessarily the best solution in all supply chain cases; limited integration may be useful in several functional areas depending on different national and industrial contexts. Donaldson (2011) analyzes the impact of customer integration on efficiency and the role of supplier integration moderation. Wong, Boon-itt, and Wong (2011) stated that under environmental uncertainty, supplier, customer, shipping integration, flexibility performance, and the relationship between internal integration, product quality and operational costs is high.

\subsection{Internal Integration}

Internal integration is a process of interaction between organizational functions, collaboration, coordination, communication, and cooperation that unites various functional departments together into one cohesive organization (Flynn, Huo \& Zhao, 2010; Zhao, Huo, Selen \& yeung, 2011). Internal integration is defined to what extent the company is able to develop organizational strategies, as well as the implementation process in a collaborative condition so that synchronization occurs to meet customer satisfaction and interact efficiently with supplier partners (Flynn, Huo \& Zhao, 2010). Internal integration is related to the integration of information relations between departments of the organization, creating access to information on the management of service products, developing integrated data sources that are easily accessible, covering key operational data, integrating production processes (operational) using information systems, connecting production (operational) and marketing departments using digital planning systems (Lee, Kwon \& Severance, 2007; Belvedere \& Grando, 2017).

Supply chain partners are able to produce regular information exchanges and work together as a single entity and can better understand customer needs which, therefore, can respond to marketing changes more quickly (Stein, 1998). Companies with a low internal integration strategy will achieve a low level of external integration, and companies implementing a full internal integration strategy will have the highest level of external integration (Gimenez and Ventura, 2005; Belvedere \& Grando, 2017).

\subsection{Supply Chain Integration}

According to Zhao et al. (2011), the business environment is increasingly challenging and competitive, companies are trying to compete in various business fields. However, there are still many companies facing difficulty to compete in the market by only relying on internal resources and the company's own core competencies. Therefore, companies must collaborate with suppliers and customers to obtain complementary information and resources, which can be used to build competitive advantage. Li et al. (2004) define supplier integration as a long-term relationship between companies and suppliers. It is designed to utilize the strategic and operational capabilities of each company's supplier partners involved, so that it can help the company achieve the benefits of sustainable excellence. Echtelt et al. (2008) stated that supplier integration is characterized by various aspects and activities such as sharing information, coordinating with each other, increasing trust, using shared technology, carrying out integrated processes, long-term contracts, helping suppliers improve production processes, driving improvement quality, investing in supplier assets including developing new service products, increasing the ability of overall partner suppliers, sharing risks and rewards, and obtaining joint benefits from the results of developing joint efforts in integrated supply chain. The results of supply chain integration are better decision making, increasing knowledge dissemination, increasing capabilities, building learning routines, and improving the performance of supply chain partners. And according to Sahay (2003), trust with supplier partners and customers will increase the degree of commitment between the parties involved, reduce transactional costs, increase cooperation, increase the satisfaction of each party, reduce formal contracts and reduce conflicts. Frohlich and Westbrook (2001) state supplier integration refers to the process of interaction and collaboration with supplier companies to ensure effective inventory flow (Zhao et al., 2011). Placing activities with suppliers is a strategic activity which includes involving the ability of suppliers to produce new products during the design, improving the efficiency of production planning and inventory management stages, have an 
order processing system, provide quick responses with suppliers, improve supplier networks to ensure reliable delivery and exchange information with supplier partners. According to Yao, Evers \& Dresner (2007), supplier integration is concerned with the flow of data between two or more companies and is a way to achieve an integration process with suppliers who are able to take over the logistics and purchasing functions of customers.

\subsection{Customer Integration}

Tan et al. (1998) define customer integration as a demand management practice through long-term customer relations, increased satisfaction, and customer complaint management. The basic aspect of customer relations is the main focus on customers by understanding their needs and wants and satisfying customers. Various activities in customer integration such as initiatives to practice solving customer problems (complaints) in an integrated manner, direct contact with customers, manage customer complaints, improve customer satisfaction and build long-term relationships with customers (Sousa, 2003; Tan et al., 1998). Customer integration is expected to produce more benefits for the company including the ability to differentiate service products from competing companies, increase market share and retain good and profitable customers, increase customer loyalty, have the ability to quickly solve potential problems with customers and suppliers, share knowledge and expertise about new technology, a deep and rapid understanding of customer needs (Magretta, 1998; Wasti \& Jeffrey, 1999). Frohlich and Westbrook (2001) state customer integration refers to the process of interaction and collaboration between companies and customers to ensure an effective flow of products and services to customers. Customer integration involves sharing demand information that greatly helps the company understand customer needs better, improve customer demand forecasts and customer engagement collaboration with respect to product design services, providing better quality products at lower costs and more flexibility in responding to customer requests (Flynn, Huo \& Zhao, 2010). Customer activities involve the process of planning, implementing, and evaluating relationships between service suppliers and service recipients. The focus of Customer Relationship Management is not only on customer relations with the company, but also includes customer relationships in Supply Chain Management. Customer activities involve communication capabilities, delivery of service products to customers as end users, both locally and globally. Customer activities intrinsically share product information services with customers, receive customer orders, interact with customers to manage requests, share order status with customers during scheduling and provide information during the product delivery phase (Belvedere \& Grando, 2017).

\section{Hyphotesis Development}

\subsection{Supply Chain Integration}

Supply chain integration theory is often used to understand organizational problems from a contextual perspective (Jayaram, Kannan \& Tan, 2004). Supply chain integration theory suggests that organizations must align the structure and process of activities with the environment to improve company performance (Petersen, Handfield \& Ragatz, 2005). In supply chains integration, customers and suppliers can be considered an important part of the company's performance. According to Supply Chain Integration theory, organizational performance is influenced by how to align operational practices (Pagell, 2004) and individual dimensions of Supply Chain Integration must be adjusted to improve company performance in accordance with the environment in which organization operates in forming structures and processes.

\subsection{Internal Integration and Company Performance}

Internal integration is able to break down hierarchical barriers and enhance cooperation in meeting customer needs, rather than only operating in the functional environment of traditionally related departments or specialties, which are expected to be able to relate and improve company performance. Internal integration increases the amount and variety of information available to companies (Muntaka, Haruna \& Mensah, 2015). In addition, interactions often occur with different perspectives that can reduce errors and waste, open new opportunities for simplification while achieving the same engineering. From the above understanding, internal integration is the basis of Supply Chain Integration and is positively related to the company's operational and financial performance. Previous research has found that elements of internal integration such as collaboration and integration of cross-functional management systems for service management products have a positive impact on company performance (Scott, O'Leary-Kelly and Flores, 2002; Rosenzweig, Roth \& Dean, 2003; Vickery , Jayaram, Droge \& Calantone, 2003; Belvedere \& Grando, 2017). Thus, the proposed hypothesis is as follows:

$\mathrm{H}_{1}$ : There is a significant influence between Internal Supply Chain Integration on Company Performance.

\subsection{Customer Relations and Supplier Integration with Company Performance}

According to the results of Homburg \& Stock's research (2004), close relationships between customers and producers offer opportunities to improve the accuracy of demand information that reduces service product design, production planning time and outdated service products that allow it to become more responsive to customer needs, generating opportunities to utilize intelligence embedded in collaborative processes, thereby enabling companies to reduce operating costs, create greater value 
and detect changes in market demand more quickly. Belvedere \& Grando (2017) state customer integration involves sharing demand information; interacting with customers to regulate service products' reliability, responsiveness and other standards to better understand customer needs and better predict customer demand, customer collaborative involvement with respect to product design services, the provision of better quality service products at lower costs and more flexibility, so that they can immediately respond to customer needs. To implement customer and supplier integration successfully, companies need to do internal integration well, because the function of internal integration is as a coordination and learning mechanism in customer and supplier integration (Marquez et al., 2004). Customer integration and supplier integration expand internal integration by forming cross-functional teams integrating external organizations (customers and suppliers). Thus, the proposed hypotheses are as follows:

$\mathrm{H}_{2}$ : There is a significant influence between Customer Integration on Company Performance.

$\mathrm{H}_{3}$ : There is a significant influence between Supplier Integration on Company Performance.

\section{Research Method}

The research method uses a cross-sectional survey design by distributing questionnaires to collect data from respondents taken from a travel agency in North Jakarta, conducted in January 2019 to April 2019. From 300 questionnaires distributed, there were 262 questionnaires that could be used to be analyzed. The respondent department consists of supply chain departments (Ticketing, Inbound, Outbound, Documentation, Finance, MICE, \& Incentive Tour) who are directly involved in supply chain activities with customers, suppliers and internal company. Through the use of purposive sampling technique by using certain criteria (Sekaran \& Bougie, 2018), namely respondents involved in supply chain, both internal and external from a travel bureau company in North Jakarta. The number of samples use the following criteria: a minimum of $5 \mathrm{x}$ the number of questionnaire question indicators (Hair, Anderson, Tatham \& Black, 2014).

\section{Table 1}

Variable \& Operational Indicators

\begin{tabular}{|c|c|c|c|c|}
\hline No. & Construct & Variable & Dimension & Indicators \\
\hline 1 & $\begin{array}{l}\text { Antecedents of } \\
\text { Supply Chain }\end{array}$ & $\begin{array}{l}\text { Internal Integration } \\
\text { Source: Scott, O’Leary- } \\
\text { Kelly and Flores, } \\
\text { (2002); Rosenzweig, } \\
\text { Roth \& Dean, (2003); } \\
\text { Vickery, Jayaram, } \\
\text { Droge \& Calantone, } \\
\text { (2003); Muntaka, } \\
\text { Haruna \& Mensah } \\
\text { (2015). }\end{array}$ & $\begin{array}{ll}\text { - } & \text { Periodic meetings of internal } \\
\text { functions between departments } \\
\text { - } \\
\text { Integrated logistics management of } \\
\text { products \& services }\end{array}$ & $\begin{array}{ll}\text { - } & \text { Establish contact between department } \\
\text { functions more often with each other } \\
\text { - }\end{array}$ \\
\hline 2 & Integration & $\begin{array}{l}\text { Supplier Integration } \\
\text { Source: } \\
\text { Homburg and Stock, } \\
\text { (2004); Marquez, } \\
\text { Bianchi \& Gupta } \\
\text { (2004); Muntaka, } \\
\text { Haruna \& Mensah } \\
(2015) \text {. }\end{array}$ & $\begin{array}{l}\text { - The level of strategic partnership } \\
\text { with major suppliers } \\
\text { - The level of involvement of major } \\
\text { suppliers in the organization's } \\
\text { planning and setting company goals }\end{array}$ & $\begin{array}{l}\text { - The level of strategic partnership with } \\
\text { suppliers } \\
\text { - The level of organizational reliability } \\
\text { with suppliers } \\
\text { - The level of information exchange with } \\
\text { suppliers through the information } \\
\text { network } \\
\text { - The level of supplier participation in the } \\
\text { design of service products }\end{array}$ \\
\hline 3 & & $\begin{array}{l}\text { Customer Integration } \\
\text { Source: } \\
\text { Homburg and Stock, } \\
\text { (2004); Marquez, } \\
\text { Bianchi \& Gupta } \\
\text { (2004); Muntaka, } \\
\text { Haruna \& Mensah } \\
\text { (2015). }\end{array}$ & $\begin{array}{l}\text { Frequent interactions with } \\
\text { customers in terms of reliability, } \\
\text { responsiveness and other service } \\
\text { standards. } \\
\text { The level of further action from the } \\
\text { company towards feedback on the } \\
\text { quality of the company's services. }\end{array}$ & $\begin{array}{l}\text { - } \quad \begin{array}{l}\text { Periodic contact with customers } \\
\text { - }\end{array} \text { services } \\
\text { - } \quad \text { The level of communication with } \\
\text { customers } \\
\text { - } \quad \text { Follow up on customer feedback } \\
\text { - } \quad \text { Customers order online } \\
\text { - } \quad \text { Share information with customers } \\
\text { - } \quad \text { Computerization make it easy to order } \\
\text { - } \quad \text { Reliable, responsive and other standard } \\
\text { customer interactions. } \\
\text { - A fast ordering system with customers. } \\
\text { - Frequency measurement and feedback } \\
\text { evaluation with customers. }\end{array}$ \\
\hline 4 & Performance & $\begin{array}{l}\text { Company Performance } \\
\text { Source: } \\
\text { Petersen, Handfield \& } \\
\text { Ragatz (2005); Pagell } \\
\text { (2004); Muntaka, } \\
\text { Haruna \& Mensah } \\
(2015) .\end{array}$ & $\begin{array}{l}\text { - The rate of modification of } \\
\text { service products in meeting } \\
\text { customer demand. } \\
\text { - } \quad \text { On time delivery of service } \\
\text { products to customers. } \\
\text { - Annual sales results. }\end{array}$ & $\begin{array}{ll}\text { - } & \text { Sales volume increases } \\
\text { - } & \text { On time sales. } \\
\text { - } & \text { Organizational performance. } \\
\text { - } & \text { Timely delivery of service products. } \\
\text { - } & \text { Modification of service products that } \\
& \begin{array}{l}\text { are fast and in accordance with } \\
\text { customer needs. }\end{array}\end{array}$ \\
\hline
\end{tabular}

Source: Processed Data Results (2020) 
Descriptive profiles of 262 respondents consisted of 180 men $(68.7 \%)$ and 82 women $(31.3 \%)$. High school education equal to 62 respondents $(23.7 \%), \mathrm{S} 1$ (Graduate) as many as 153 respondents $(58.4 \%)$, and $47 \mathrm{~S} 2$ (graduate) respondents (17.9\%). A total of 68 respondents $(26.0 \%)$ worked in the Ticketing Department, 56 respondents $(21.4 \%)$ in the Inbound Tour Department, 48 respondents $(18.3 \%)$ in the Outbound Tour, 32 respondents $(12.2 \%)$ in the Department Documentation, 17 respondents $(6.5 \%)$ in the Department of Finance, 23 respondents $(8.7 \%)$ in the MICE Department, and 18 respondents $(6.9 \%)$ in the Incentive Tour Department). By using Exploratory Factor Analysis (EFA) to conduct a contract analysis of Supply Chain Integration Antecedents and Company Performance, and varimax rotation to assess the validity of Supply Chain Integration Antecedents construct and Company Performance. To test the appropriateness of the use of factor analysis, the Bartlett (sphericity) or MSA (Measure Sampling Adequacy) and Kaiser-Meyer-Olkin (KMO) tests are used to measure the adequacy of the sample. The KMO size value of the adequacy of the sample must be greater than 0.7 and not adequate if it is less than 0.5. The Bartlett test is significant at a significance value of less than 0.05 (Leech, Barrett \& Morgan, 2005). From the calculation results, KMO values 0.715 above the recommendation level of 0.7 so that the sample data collected is feasible from factor analysis. According to Frohlich and Westbrook (2001), research data generated using interval scale responses also need to be tested for reliability. Reliability analysis was performed by calculating Cronbach Alpha to test the internal consistency of each factor (indicator) of the main construct of research model. The test results show that the Cronbach Alpha of four major constructs exceeds the threshold point of 0.70 as suggested by Nunnally (1978). The construct and relationship of variables is presented in the Research Model Framework in Fig. 1.

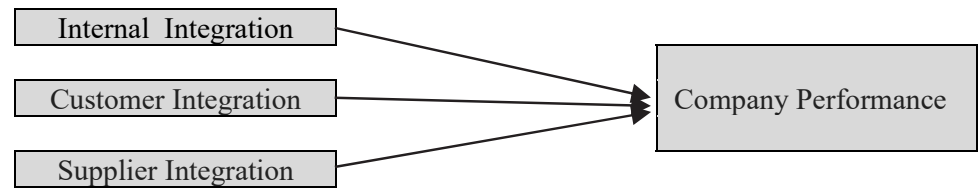

Fig. 1. Research Model Framework

\section{Discussion of Research Results}

Questionnaires were collected, reviewed for completeness and accuracy, then sorted and coded using SPSS software. Researchers used the Chi-square test to analyze the extent to which Supply Chain Integration Antecedents affect the Company Performance of the travel bureau in North Jakarta. For supply chain integration antecedents' variables, namely Internal Integration, Supplier Integration, and Customer Integration, and Company Performance, a factor analysis (validity) and reliability test (Sekaran \& Bougie, 2018) were tested. Exploratory factor analysis results show that each indicator has a factor load value having a significance Eigen value exceeding 2, with cumulative variance values ranging between 35,304 and 100. The KMO (Kaiser-Meyer-Olkin) value is 0.715 and shows a significant Chi-square value (Barlett sphericity test =33.90). This places the KMO estimate for our study above the threshold value of 0.50 recommended by Hair, Anderson, Tatham \& Black (2014). The loading factor of all constructs in the study is quite high, thus making the findings of this study significant and meaningful.

Table 1

Descriptive Factor Analysis \& Statistics

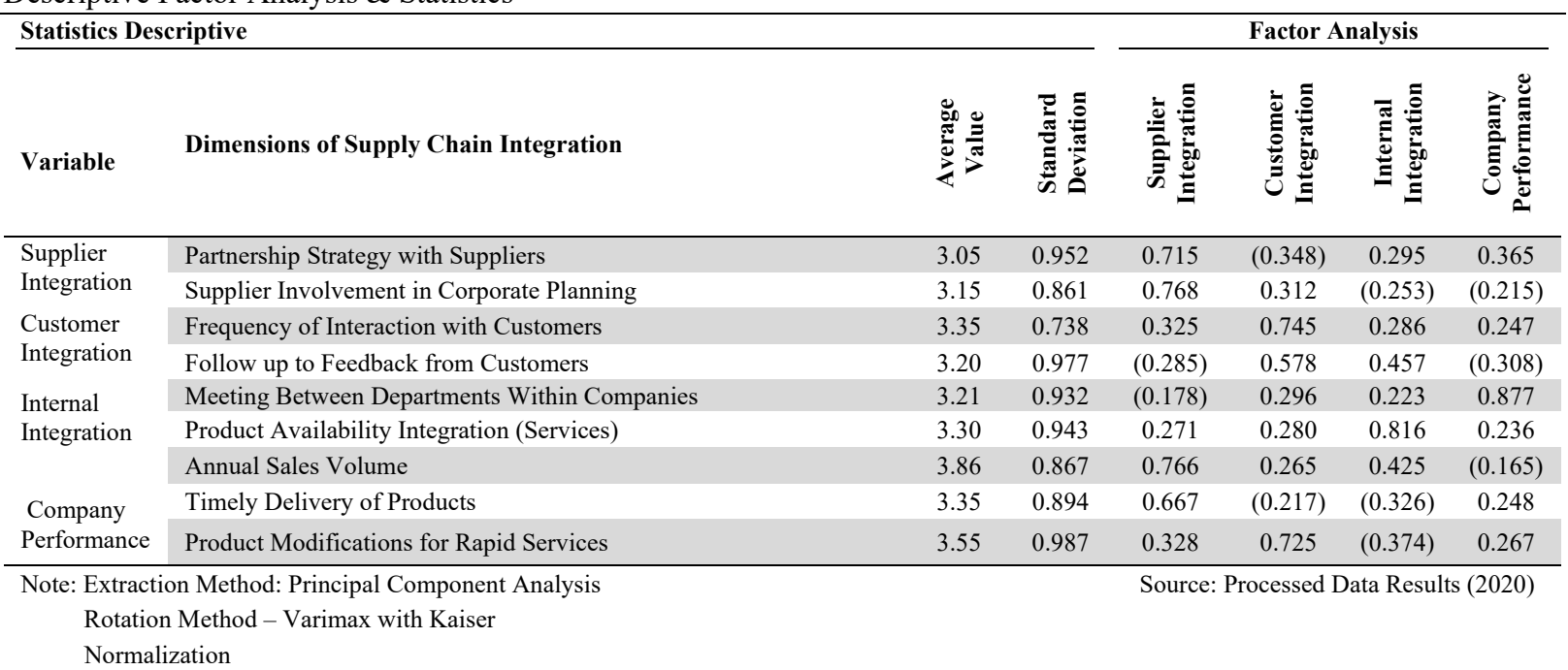

Table 1 shows a summary of descriptive statistics and factor analysis, the results show that among the antecedent variables of Supply Chain Integration, namely Supplier Integration, the level of Strategic Partnership with suppliers shows the highest 
average value (3.95), followed by the level of Organization Reliability at Suppliers ( 3.63), Exchange of Information with Suppliers through Information Network (3.50) and Supplier Participation in Product Design Services (3.40). In Internal Integration, the Level of Frequent Contact Between Departments in Supply Chain with Each Other has the highest average value (4.33), followed by the Cross Functional Team in Process Improvement (4.19); and Product Management Services Integration Services (4.10) and Organizational Integration Applications (4.06). In the Customer Integration variable, Periodic Contact with Customers has the highest average value (4.57), followed by the Speed of Ordering Process (4.21), Communication Level with Customers (4.13), Following Up with Customer Feedback (4.11), Customers Order Online (3.70) and Share Marketing Information (3.10). For Customer Integration variable, the highest average value in Computerized Ordering Makes it easier for Customers (4.72); Frequent Interactions with Reliable, Responsive and Other Standard Customers (4,52); Rapid Ordering System with Customers (4.33) and Frequency Measurement and Feedback Evaluation with Customers (4.01). Company Performance Variable, the average value of Sales Volume and Timeliness of 5.31; followed by an average value of Operational Performance of 4.05; the average value of the On-Time Delivery Record is 3.93; and Product Modification of Services that are Fast and In Accordance with Customer's Needs of 3.98. Table 2 explains the weighted value of standard regression, according to the research model in Figure 1, there are partially supported hypotheses, generally indicating that Supply Chain Integration is related to Company Performance. Specifically, the application of Supply Chain Integration contingency approach shows that Internal Integration is directly related to Operational Performance $(\alpha=0.032<0.05)$; and Customer Integration is directly related to Operational Performance. Although Supplier Integration is not directly related to Company Performance, interaction between Supplier Integration and Customer Integration relates to Operational Performance, explained by each p-value, which is equal to 0.038 and $0.032<0.05$. The most significant variables are Organizational Follow Up, Meetings Between Departments, interacting with Customer Involvement and Supplier Involvement.

\section{Table 2}

\begin{tabular}{llc} 
Weighted Value of Standard Regression & Standard Estimation Value \\
\hline No. & Information & 0.217 \\
\hline 1 & Strategic Partnership $\rightarrow$ Product Modification Services & 0.261 \\
2 & Strategic Partnership $\rightarrow$ On time Delivery & 0.038 \\
3 & Interaction with Customers $\rightarrow$ Product Modification Services & -0.03 \\
4 & Organizational Follow Up $\rightarrow$ Product Modification Services & -0.203 \\
5 & Supplier Involvement $\rightarrow$ Product Modification Services & -0.032 \\
6 & Supplier Involvement $\rightarrow$ On time Delivery & 0.041 \\
7 & Interaction with Customers $\rightarrow$ On time Delivery & 0.019 \\
8 & Organizational Follow Up $\rightarrow$ On time Delivery & 0.034 \\
9 & Product Modification Services $\rightarrow$ Sales Volume & 0.103 \\
10 & On time Delivery $\rightarrow$ Sales Volume & 0.042 \\
12 & Meeting between Departments $\rightarrow$ Sales Volume & 0.105 \\
\hline Sour & Integration of Services Product Stock $\rightarrow$ Sales Volume & \\
\hline
\end{tabular}

Source: Processed Data Results (2020)

The results of this study support previous Supply Chain Integration research (Droge et al., 2004; Germain \& Iyer, 2006; Stank et al., 2001). It is evident that Internal Integration is significantly related to Operational Performance. The results of the study reinforce the importance of Internal Integration in improving Company Performance. The findings of this study are important because much of the existing literature on Supply Chain Integration has not considered Internal Integration as an antecedent of one of the dimensions of Supply Chain Integration. The results showed that Customer Integration was significantly related to Company Performance. This is consistent with the results of previous studies (Germain \& Iyer, 2006; Koufteros et al., 2005). However, the results of this study do not support the research results of Devaraj et al. (2007) which states that customer integration has an indirect effect on Operational Performance. The results show that Supplier Integration is negatively related to certain aspects of Operational Performance, the results of this study are consistent with the findings of Stank et al. (2001), but do not support the research of Devaraj et al. (2007) who found a positive relationship between Supplier Integration and Operational Performance. The Pearson correlation results testing interaction between Supply Chain Integration and Company Performance, showing that the dimensions of Company Performance have a high correlation value with Customer Integration especially with Frequent Interactions with Customers to set Reliability, Responsiveness and other Standards $(r=0.56)$ and by Internal Integration, especially at Periodic Meetings Between Internal Functions of the Department $(\mathrm{r}=0.53)$. Operational Performance has a high correlation with Periodic Meetings Between Internal Functions of the Department $(\mathrm{r}=0.54)$, followed by Frequent Follow-Up with Customers Against Customer Feedback on Service Product Quality $(r=0.55)$ and Integrated Service Product Management $(r=0.51)$.

\section{Conclusions and Suggestions}

The results highlight a direct relationship between Internal Integration and the company's operational performance and can support Hypothesis 1, which states there is a relationship between Internal Integration and Company Performance. In addition, the results of the study show that Customer Integration influences Company Performance, especially in interactions that are often carried out with customers to regulate reliability, responsiveness and other standards in meeting customer needs, thus the results of this study support Hypothesis 2, which states that Customer Integration directly affects 
Company Performance however, it does not affect Supplier Integration. However, the results of the study do not support Hypothesis 3, which states that Supplier Integration affects Company Performance.

\section{Theoretical Implications}

This research was built using the theory of Supply Chain Integration by testing the application of theory to the travel bureau in North Jakarta. The theoretical implication is to supplement the existing literature by testing empirically the relationship between Antecedents of Supply Chain Integration and Company Performance. The results showed a significant correlation between Internal Integration and Customer Integration with Company Performance. Supply Chain Integration must focus on achieving desired company goals including customer interactions that have unlimited desires, by frequently following up with customers as feedback on the quality of the company's service products, periodic meetings between functional departments and product and service management integrated. The implication of this relationship between Supply Chain Integration and supply chain partners affects company business performance, individually and collectively. Therefore, the results of the study conclude that Supply Chain Integration is an important company resource to improve the company's business performance and aiding to face the increasingly fierce competition in the travel bureau industry. The results of this study provide a significant contribution to the Supply Chain Integration literature and have important managerial implications in business practice, but the results of this study still have some limitations, providing opportunities for further research in the future as follows:

1. this study uses a cross-sectional design which means causality research cannot be carried out, because integration between customers, suppliers and suppliers changes over time, this is useful for future research to examine the evolution of Supply Chain Integration patterns in longitudinal mode.

2. Data is only collected from the travel bureau in North Jakarta, future research can broaden its scope by gathering data from all supply chain partners including suppliers, manufacturers, and customers.

3. Although this study provides some interesting findings about the relationship between Supply Chain Integration and Corporate Performance in the travel bureau, it is still unclear whether this relationship will be the same as other types of industries in other regions with different target populations.

4. Future research must examine other Supply Chain Integration factors, such as competitive environment, commitment to relationships, trustworthiness, organizational characteristics, national culture, company size, and type of ownership using SEM (Structural Equation Modeling) to test the suitability of the research model as well as direct and indirect effects between latent variables.

\section{References}

Bagchi, P. K. \& Chun H. B. (2005). Supply Chain Integration: a European survey. The International Journal of Logistics Management, 16(2), 275-294.

Bask, A. H. \& Juga, J. (2001). Semi-integrated supply chains: Towards the new era of supply chain management. International Journal of Logistics: Research and Applications, 3(1), 5-23.

Belvedere, V. \& Grando, A. (2017). Sustainable Operations and Supply Chain Management. Wiley series in Operation Research and Management Science, John Wiley 7 Sons Ltd. ISBN 97811192366.

Cespedes, F. (1996). Beyond teamwork: How the wise can synchronize. Marketing Management, 5(1), 25-37.

Cousins, P. D. \& Menguc, B. (2006). The implications of socialization and integration in supply chain management. Journal of Operations Management, 24(5), 604-620.

Donaldson, L. (2011). The Contingency Theory of Organizations. Thousand Oaks, CA: Sage.

Droge, C., Jayaram, J., \& Vickery, S. K. (2004). The effects of internal versus external integration practices on time-based performance and overall firm performance. Journal of Operations Management, 22(6), 557-573.

Danese, P. \& Romano, P. (2011). Supply chain integration and efficiency performance: A study on the interactions between customer and supplier integration. Supply Chain Management: An International Journal, 16(4), 220-230.

Das, A., Narasimhan, R., \& Talluri, S. (2006). Supplier integration - finding an optimal configuration. Journal of Operations Management, 24(5), 563-582.

Devaraj, S., Krajewski, L. \& and Wei, J. C. (2007). Impact of e-business technologies on operational performance: The role of production information in the supply chain. Journal of Operations Management, 25(6), 1199-1216.

Echtelt, F., Wynstra, F., Weele, A., \& Duysters, G. (2008). Managing supplier involvement in new product development: A multiple-case study. The Journal of Product Innovation Management, 25(2), 180-201.

Elmuti, D., Minnis, W., \& Abebe, M. (2008). Longitudinal assessment of an integrated industrial supply chain. Supply Chain Management: An International Journal, 13(2), 151-159.

Evans, M. M. (2015). Impact of Supply Chain Integration Strategies on Performance of Pork Processing Industry in Rwanda (case of German butchery in Kigali). European Centre for Research Training and Development UK (www.eajournals.org).

Flynn, B. B., Huo, B., \& Zhao, X. (2010). The impact of supply chain integration on performance: A contingency and configuration approach. Journal of Operations Management, 28(1), 58-71. 
Frohlich, M. T. \& Westbrook, R. (2001). Arcs of integration: An international study of supply chain strategies. Journal of Operations Management, 19(2), 185-200.

Germain, R. \& Iyer, K. N. S. (2006). The interaction of internal and downstream integration and its association with performance. Journal of Business Logistics, 27(2), 29-53.

Gibson, B. J., Mentzer, J. T., \& Cook, R. L. (2005). Supply chain management: The pursuit of a consensus definition. Journal of Business Logistics, 26(2), 17-25.

Gimenez, C. \& Ventura, E. (2005). Logistics-production, logistics-marketing and external integration: Their impact on performance. International Journal of Operations and Production Management, 25(1), 20-38.

Gimenez, C., van der Vaart, T., \& van Donk (2012). Supply chain integration and performance: The moderating effect of supply complexity. International Journal of Operations and Production Management, 32(5), 583-610.

Hair J. F., Anderson, R. E., Tatham, R. L., \& Black, W. C. (2014). Multivariate data analysis. $7^{\text {th }}$ Edition, Englewood Cliffs, NJ: Prentice-Hall. ISBN 10: 1-292-02190-X; ISBN 13: 978-1-292-02190-4

Homburg, C., \& Stock, R. M. (2004). The link between salespeople's job satisfaction and customer satisfaction in a business-to-business context: A dyadic analysis. Journal of Academy of Marketing Science, 32(2), 144-158.

Jayaram, J., Kannan, V. R., \& Tan, K. C. (2004). Influence of initiators on supply chain value creation. International Journal of Production Research, 20, 4377-4399.

Jie, F., Parton, K. A. \& Cox, R. J. (2013). Linking supply chain practices to competitive advantage: An example from Australian agribusiness, British Food Journal, 115(7), 1003-1024. http://dx.doi.org/10.1108/BFJ-10-2010-0181

Jin, Y. H. J., Fawcett, A. M. \& Fawcett, S. E. (2013). Awareness is not enough: Commitment and performance implications of supply chain integration, International Journal of Physical Distribution \& Logistics Management 43(3), $205-230$.

Kahn, K. B. and Mentzer, J. T. (1996). Logistics and interdepartmental integration. International Journal of Physical Distribution and Logistics Management, 26(8), 6-16.

Kim, S. W. (2006). Effects of supply chain management practices, integration and competition capability on performance. Supply Chain Management: An International Journal, 11(3), 241-248.

Kingman-Brundage, J., George, W., and Bowen, D. (1995). Service Logic: Achieving Service System Integration. International Journal of Service Industry Management, 6(4), 20-39.

Klueber, R. \& O'Keefe, R. M. (2013). Defining and assessing equisite supply chain visibility in Regulated industries, Journal of Enterprise Information Management, 26(3), 295-315. http://dx.doi.org/10.1108/17410391311325243

Koufteros, X., Vonderembse, M., \& Jayaram, J. (2005). Internal and external integration for product development: The contingency effects of uncertainty, equivocality, and platform strategy. Decision Science, 36(1), 97-133.

Koufteros, X. A., Cheng, T. C. E., and Lai, K. H. (2007). Black-Box and gray box supplier integration in product development: Antecedents, consequences and the moderating role of firm size. Journal of Operations Management, 25(4), 847-870.

Lambert, D. \& Cooper, M. (2000). Issue in supply chain management. Industrial Marketing Management, 29(1), 65-83.

Lambert, D. M., Cooper, M. C., \& Pagh, J. D. (2000). Supply chain management: Implementing issues and research opportunities. International Journal of Logistics Management, 9(2), 1-19.

Lee, C. W., Kwon, I. W. C., \& Severance, D. (2007). Relationship between supply chain performance and degree of linkage among supplier, internal integration, and customer. Supply Chain Management: An International Journal, 12(6), 444452.

Leech, N. L., Barret, K. C., \& Morgan, G. A. (2005). SPSS for intermediate statistics. Use and interpretation (2nd Ed.).

Mackelprang, A. W., Robinson, J. L., Bernardes, E. \& Webb, G. S. (2014). The relationship between strategic supply chain integration and performance: A meta-analytic avaluation and implications for supply chain management research. Journal of Business Logistics 35(1), 71-96. http://dx.doi.org/10.1111/jbl.12023

Magretta, J. (1998). The power of virtual integration: An interview with Dell Computers' Michael Dell. Harvard Business Review, 76(2), 72-84.

Marquez, A. C., Bianchi, C., \& Gupta, J. N. D. (2004). Operational and financial effectiveness of e-collaboration tools in supply chain integration. European Journal of Operational Research, 159(2), 348-363.

Muntaka, A. S., Haruna, A., \& Mensah, H. K. (2015). Supply chain integration and flexibility and its impact on performance. International Journal of Business and Management, 12(4), 130-141.

Narasimhan, R., \& Kim, S. W. (2002). Effects of supply chain integration on the relationship between diversification and performance: Evidence from Japanese and Korean Firms. Journal of Operations Management, 20(3), $303-323$.

Nunnally, J. (1978). Psychometric Theory. New York, NY: McGraw-Hill.

Pagell, M. (2004), Understanding the factors that enable and inhibit the integration of operations, purchasing and logistics. Journal of Operations Management, 22(5), 459-487.

Palma-Mendoza, J. A., Neailey, K., \& Roy, R. (2014). Business process re-design methodology to support supply chain integration, International Journal of Information Management 34(1), 167-176.

Papakiriakopoulos, D. \& Pramatari, K. (2010). Collaborative performance measurement in supply chain. Industrial Management \& Data Systems, 110(9), 1297-1318. http://dx.doi.org/10.1108/02635571011087400

Petersen, K., Handfield, R., \& Ragatz, G. (2005). Supplier integration into new product development: Coordinating product, process, and supply chain design. Journal of Operations Management, 23(3/4), 371-388.

Qi, Y., Zhao, X., \& Sheu, C. (2011). The impact of competitive strategy and supply chain strategy on business performance: The role of environmental uncertainty. Decision Sciences, 42(2), 371-389. 
Richey, R. Jr., Chen, H., Upreti, R., Fawcett, S. E., \& Adams, F. G. (2009). The moderating role of barriers on the relationship between drivers to supply chain integration and firm performance, International Journal of Physical Distribution \& Logistic Management, 39(10), 826-840.

Rosenzweig, E. D., Roth, A. V., \& Dean, G. V. (2003), The influence of an integration strategy on competitive capabilities and business performance: An exploratory study of consumer product manufacturers. Journal of Operations Management, 21(4), 437-456.

Sahay, B. S. (2003). Understanding trust in supply chain relationships. Industrial Management and Data Systems, 103(8), 553-563.

Sekaran, U., \& Boogie, R. (2018). Research Methods for Business - A Skill Building Approach, $7^{\text {th }}$ Edition, John Wiley \& Sons, Ltd.

Scott, W., O'Leary-Kelly, \& Flores, B. E. (2002). The integration of manufacturing and marketing/sales decisions: Impact on organizational performance. Journal of Operations Management, 20(3), 221-240.

Sousa, R. (2003). Linking quality management to manufacturing strategy: An empirical investigation of customer focus practices. Journal of Operations Management, 21(1), 1-18.

Song, M., \& Di Benedetto, C. A. (2008), Supplier's involvement and success of radical new product development in new ventures. Journal of Operations Management, 26(1), 1-22.

Stein, T. J. S. (1998). Killer Supply Chain. Information Weak, 708: 36-46.

Stank, T. P., Keller, S. B., \& Closs, D. J. (2001), Performance Benefits of Supply chain integration. Transportation Journal, 41(2), 31-46.

Tan, K. C., Kannan, V. R., \& Handfield, R. B. (1998), Supply chain management: Supplier Pperformance and firm performance. International Journal of Purchasing and Materials Management, 3, 2-9.

Tseng, P. \& Liao, C. (2015). Supply chain integration, information technology, market orientation and firm performance in container shipping firms. The International Journal of Logistics Management, 26(1), 82-106.

Vaart, Van der, T., \& Van Donk, D. (2008). A critical review on survey-based research in supply chain integration. International Journal of Production Economics, 111(1), 42-55.

Vickery, S.K., Jayaram, J., Droge, C., \& Calantone, R. (2003), The effects of an integrative supply chain strategy on customer service and financial performance: An analysis of direct versus indirect relationships. Journal of Operations Management, 21(5), 523-539.

Wasti, S., \& Jeffrey, L. (1999). Collaborating with suppliers in product development: A U.S. and Japan comparative study. IEEE Transactions on Engineering Management, 46(2), 245-257.

Wisner, J. D. \& Tan, K. C. (2000), Supply chain management and its impact on purchasing. Journal of Supply Chain Management, 36(4), 33-42.

Wong, C. Y., Boon-itt, S., \& Wong, C. W. Y. (2011). The contingency effects of environmental uncertainty on the relationship between supply chain integration and operational performance. Journal of Operations Management, 29(6), 604-615.

Yao, Y., Evers, P. T., \& Dresner, M. E. (2007). Supply chain integration in vendor managed inventory. Decision Support Systems, 43(2), 663-674.

Yeung, J. H. Y., Selen, W., Zhang, M., \& Huo, B. (2009). The effects of trust and coercive power on supplier integration. International Journal of Production Economics, 120(1), 66-78.

Xu, D. H., Huo, B. F., \& Sun, L. Y. (2014). Relationship between intra-organizational resources, supply chain integration and business performance: An extended resource-based view. Industrial Management \& Data Systems, 114(8), 11960156. DOI:10.1108/IMDS-05-2014-0156.

Zailani, S. \& Rajagopal, P. (2005). Supply chain integration and performance: US versus East Asian companies. Supply Chain Management: International Journal, 10(5), 379-393.

Zhao, X., B., Huo, Flynn, B. B., \& Yeung, J. (2008). The impact of power and commitment on the integration between manufacturers and customers in a supply chain. Journal of Operations Management, 26(3), 368-388.

Zhao, X., B. Huo, Selen, W., \& Yeung, J. (2011). The impact of internal integration on relationship commitment on external integration. Journal of Operations Management, 29(1-2), 17-32.

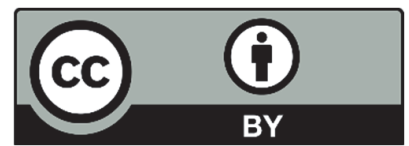

(C) 2020 by the authors; licensee Growing Science, Canada. This is an open access article distributed under the terms and conditions of the Creative Commons Attribution (CC-BY) license (http://creativecommons.org/licenses/by/4.0/). 